\title{
Analyzing The Effectiveness Of Public Policy Advertising On Attitudes And Behavioral Changes
}

Bichwi Yun, Korea Institute for Development Strategy (KDS), South Korea Yoon C. Cho, KDI School of Public Policy and Management, South Korea

\begin{abstract}
Understanding the public's interest toward public policy and advertising has become a central issue in marketing and public policy.

The purpose of the study was to investigate how the public perceives policy advertising and how their perceptions affect attitudes and behavior. This study was an exploration of the effects of public policy-related messages on conditional principles through the application of the extended Fishbein model. In particular, relationships were measured concerning 1) the effects of estimates of attitudes on the differential attitude to public policy advertising, 2) the effect of subjective norms on the differential subjective norm, 3) the effect of differential attitude and subjective norm on differential intention, and iv) the effect of differential intention on behavioral change. In particular, the effects of conditional principles, including the effects of print and television (TV) advertising, were measured. For the effects of TV advertising, both direct and indirect (e.g., product placement $[P P L]$ ) delivery formats of messages were measured.
\end{abstract}

To test the hypotheses, various statistical analyses were performed, including factor analysis, Analysis of Co-Variance (ANCOVA), Analysis of Variance (ANOVA), and regression. The results of this study suggested both theoretical and managerial implications to public policy.

Keywords: Attitudes; Behavior; Subjective Norm; Public Policy Messages

\section{INTRODUCTION}

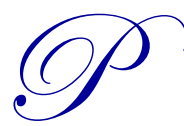

ublic policy and advertising, two critical and interrelated topics (Rotfeld and Stafford, 2007), have been applied with diverse issues by both profit and non-profit organizations. Among the integrated communication tools, in particular, public policy and advertising have been utilized to deliver messages of non-profit organizations related to government regulations and public. Public policy and advertising is also known as advocacy advertising, which often deals with corporate level concerns (Sethi, 1979) or issue advertising, which deals with public policy issues (Bergen and Risner, 2012). Public policy and advertising have been developed in considerations of their ability to effect attitudinal and social behavioral changes, such as enhanced public trust and credibility (Sethi, 1979). Bergen and Risner (2012) suggested issue advertisements can change attitudes by persuading individuals about the merits of a particular policy. In various studies, researchers have discussed the effects of public policy on marketing practices, the societal contribution of marketing, and the application of marketing practices to public policy issues (Stewart, 2013). Previous studies have indicated public policy deals with diverse aspects of social problems such as health and safety issues (Murphy, 2011), minority discrimination, crime, and poverty (Briey, Shrum, and Wyer, 2013) and with economic issues such as ways to reduce consumption expenditures and appropriate choices (Jacobson and Nicosia, 1981). Balasubramanian (1994) addressed the social implications of hybrid messages and public policy issues for policymakers by considering public awareness, attitude toward the message, and mass focusing strategies. Through the application of integrated communication tools, this study served to explore the importance of public policy messages in non-profit 
organizations, or public-centric management, which were also highlighted in the private sector as consumer-centric management (Andreasen, 2012; Levitt, 1960; Wei-Skellern Austin, Leonard, and Step, 2007; Smith, Drumwright, and Gentile, 2010).

Public policy messages, which focus on better social behavior and decisions such as warning messages (e.g., anti-smoking), have also been generated in consideration of consumers and the public in general. Based on these considerations, this study was an investigation of the ways in which public-oriented policy and promotional messages persuade the public to change attitudes and behavior to make the right decisions that are also related to social norms. By extending the theoretical and practical applications from the private sector, this study served to explore how public policy messages have been developed to deliver messages in the public sector.

The purpose of this study, in particular, was to explore how people perceive public policy advertising and how their perceptions affect their attitudes and behavior. To measure attitudinal and behavioral changes affected by public policy messages, the following research questions were used to guide this study:

1. How do attitude estimates concerning public policy, such as behavioral beliefs and evaluations, affect differential attitudes after perceiving public policy messages?

2. How do estimates of subjective norms concerning public policy, such as normative beliefs and motivations to comply, affect differential subjective norms after perceiving public policy messages?

3. How do differential attitudes toward public policy affect differential intention to switch attitude to public policy?

4. How do differential subjective norms affect differential intentions to switch attitudes to public policy?

5. How do differential intentions to switch attitudes to public policy affect behavioral change to follow the policy?

In particular, concerning the first two research questions, this study constituted a further exploration of the effects of attitude estimates on differential attitudes and the effects of estimates of subjective norms on differential subjective norms in terms of perceptions of different types of public policy messages. Thus, the following additional research questions were required:

1. How does the effect of attitude estimates on differential attitudes differ based on the different types of advertising the audience perceives, including print and television?

2. How does the effect of estimates of subjective norms on differential subjective norms differ based on the different types of advertising the audience perceives, including print and television?

In measuring the effects of TV advertising, direct versus indirect advertising was evaluated.

\section{LITERATURE REVIEW}

Various advertising tools have been designed to address public attitude and behavioral changes on social issues. Public policy involving advertising has been called issue advertising (Bergen and Risner, 2012), advocacy advertising (Sethi, 1979), and/or image advertising (Heath and Nelson, 1985) and has been concerned with diverse topics related to regulations, such as 1) government regulatory rules/decisions; 2) organizational regulatory environments, including self-regulation and other related activities; and 3) consumer-related impacts (Rotfeld and Stafford, 2006).

Public policy and advertising studies have included discussions of public awareness (Balasubramanian, 1994) and attitudes toward policy, issues and ways to persuade viewers about the merits of particular policy proposals (Bergan and Risner, 2012; Falk, Grizard, and McDonald, 2005) and changes of public opinion about a social issue (Bergen and Risner, 2012), the message information content or images that portrayed public policy regulation (Rotfeld and Stafford, 2007), and the effectiveness (Stewart and Martin, 1994) of applying traditional methods to new media, including the Internet (Taylor, 2009) and mobile media. Rotfeld and Stafford (2007) stated that guidance on public policy decisions and key issues raised in the public policy debates are topics addressed in studies of advertising message strategy, consumer behavior, or economic assessments of regulatory issues. Stewart and Martin (1994) posited multiple criteria for effectiveness and implications of public policy messages, such as 
warning messages, including types, purposes, and measures of effects. Often the emphasis in public policy advertising that deals with social and nonprofit advertising has been behavior and social changes related to regulation, donation levels/loyalty, corporate collaboration, and nonprofit/social program growth (Wei-Skellern, Austin, Leonard, and Stephenson, 2007). Among those topics, the focus in regulation-related studies were often selfregulation on Direct-to-Consumer prescription drugs (Arnold and Oakley, 2013; Liu and Gupta, 2011; Hausman, 2008), alcohol warning messages emphasizing avoidance of possible problems (Cobuild, 2001), the influence on consumer behavior (Stewart and Martin, 1994), the effects of warning label placement (Torres, Sierra, and Heiser, 2007), and the effectiveness of alcohol warning messages in the media (Barlow and Wogalter, 1993).

Both qualitative and quantitative studies have been conducted on issues of public policy and advertising. Qualitative studies included research analyzing advertising and self-regulation and societal control (Boddewyn, 1989), conceptual frameworks (Rotfeld and Stafford, 2007), image and issue advertising with corporate and public policy perspectives (Heath and Nelson, 1985), institutional images and ideas/issues concerning advertising with public policy issues (Sethi, 1979), the role of marketing research in public policy decision making (Wilkie and Gardner, 1974), consequences of warning messages and implications for public policy (Stewart and Martin 1994), and legal and public policy implications for comparative advertising (Beck-Dudley and Williams, 1989). Quantitative approaches to research on public policy and advertising issues and their effectiveness included studies on citizen-sponsored issues and attitude toward policy (Bergen and Risner, 2012), macro effects of advertising (Jacobson and Nicosiz, 1981), and effects of warning messages (Cho and Rim, 2013).

\section{HYPOTHESES DEVELOPMENT}

The issue in this was that public policy should adopt marketing principles to understand the public behavior (Brockett, Golden, and Aird, 1990). The study suggested that the adoption of such theoretical and practical information is fundamental to analyzing attitudes toward public policy and behavioral changes are fundamental to analyze the effectiveness of public policy messages through advertising. Various researchers have studied the effects of persons' attitudes on their intentions and behavior (Ajzen and Fishbein, 1980; Solomon, 2009; Blackwell, Miniard, and Engel, 2006). The relationship between attitude and behavior has been a key in predicting overt behaviors from attitudes (Cialdini, Petty, and Cacioppo, 1981). Attitudes have an important degree of predictive utility and causal predominance over behaviors (Kahle and Berman, 1979; Andrews and Kandel, 1979; Cialdini, Petty, and Cacioppo, 1981). Cialdini, Petty, and Cacioppo (1981) argued that in attitudinal phenomena, such as processing attitude-related information (e.g., message arguments), the cognitive response approach emphasizes the mediating influence of the specific cognitive reactions (e.g., counter-arguments, favorable thoughts, etc.).

Proposed theories such as the Fishbein model, behavioral learning theory, and cognitive learning theory have also been applied to the public sector to maximize the effect of public policy messages to create favorable recognition of policies. According to Ajzen and Fishbein (1980), one can explain behavior in terms of a limited number of concepts, such as beliefs, attitudes, subjective norms, and intention. According to the Fishbein model, the degree to which people like or dislike public policy may have little to do with whether or not they follow the policy. A theory of reasoned action proposed by Ajzen and Fishbein (1980) also suggested that the best predictor of behavior is the actor's intention to perform the behavior, which is based on the person's attitude toward the behavior and the subjective norm regarding the behavior (Cialdini, Petty, and Cacioppo, 1981). The theory of planned behavior also indicates that intentions and behaviors are functions of determinants, such as social influence and the individual's attitude toward the behavior (Ajzen, 2005).

The proposed model for this study was modified from the Ajzen and Fishbein (1980)'s extended Fishbein model. As shown in Figure 1, attitude estimates based on beliefs and evaluations concerning public policy lead to differential attitude. Estimates of subjective norms based on normative beliefs concerning public policy and motivations to comply lead to differential subjective norm. Both differential attitude and differential subjective norm are linked to differential intention and, finally, it comes to behavioral change. When attitude estimates and estimates of subjective norm lead, respectively, to differential attitude and differential subjective norm, public policy messages stimulate their linkage, if any. The hypothesis of this study was that the effects differ based on perceptions of the advertising that delivered the messages via different media, such as print or TV advertising and direct and non-direct advertising (PPL). 


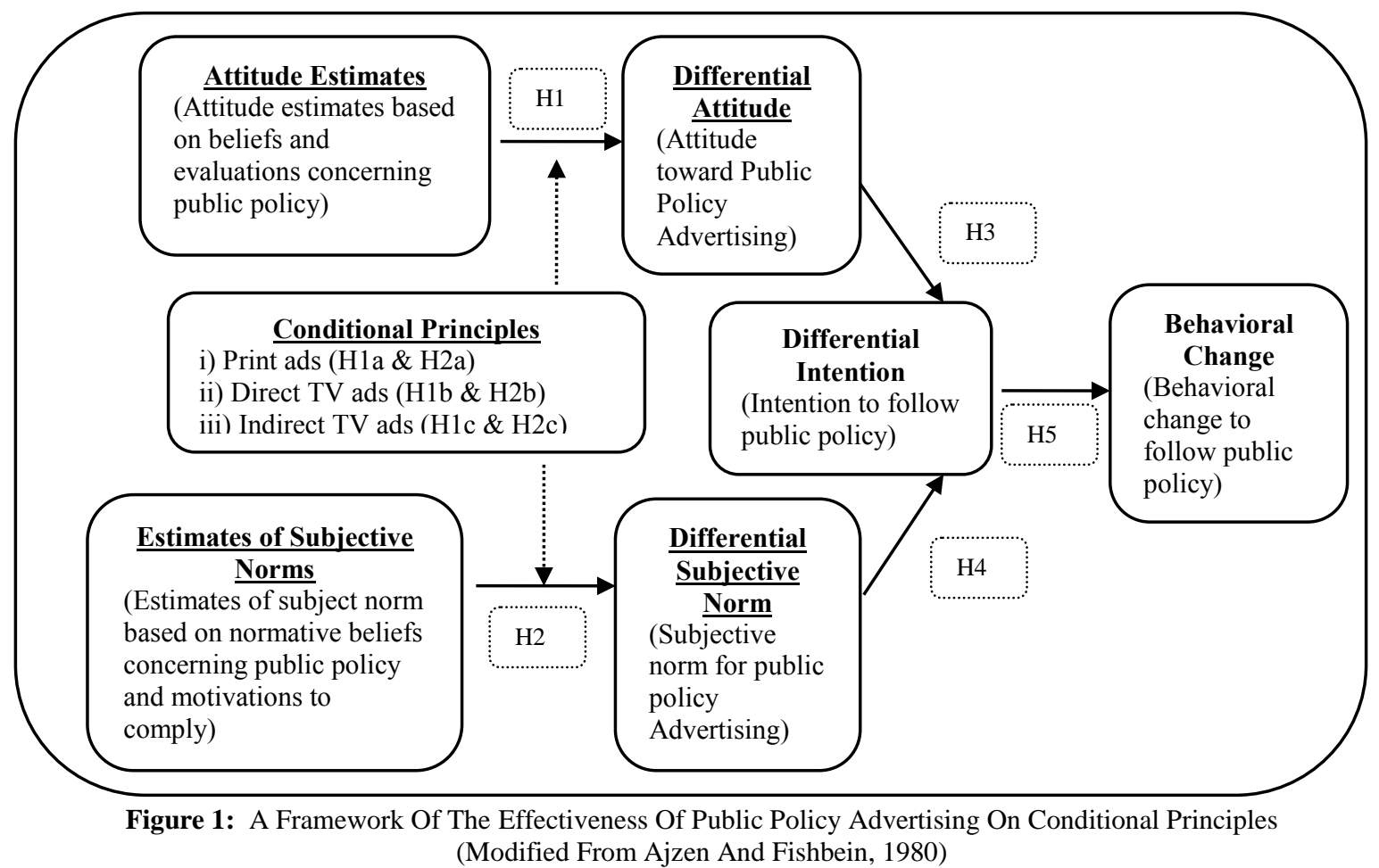

The Effects Of Attitude Estimates On Differential Attitudes Toward Public Policy Advertising

Attitudes have been defined as a "psychological construct, a way of conceptualizing the intangible" that cannot be observed or measured directly because their existence is estimated from their consequences (Aaker, Kumar and Day, 2001). Although the term attitude is widely used, Arnould, Zinkhan, and Price (2002) defined it as a consumer's overall, enduring evaluation of a concept or object, such as a person, brand, or service. Ajzen and Fishbein (1980) indicated that attitudes are determined by the set of salient beliefs an individual holds about performing the behavior. Attitude toward a behavior is also considered a person's judgment that performing the behavior is good or bad, that the person is in favor of or against performing the behavior (Ajzen and Fishbein 1980). Therefore, if a person has salient beliefs toward public policy, whether positive or negative, that person will form attitudes toward public policy messages that also affect behavior as a consequence.

Various scholars introduced theoretical background to explain how attitudes affect social behavior (Lutz, 1978). Among various attitudes, in particular, this research concerned the attitude toward advertising. Shanahan, Hopkins, and Carlson (2010) stated that attitude toward advertising is related to emotional response to an advertisement. Bagozzi and Moore (1994) suggested that when confronted with images that generate negative emotions, viewers attempt to cope in some way and that this can include empathy for the victim (as cited in Shanahan, Hopkins, and Carlson, 2010)." Batson, Bolen, Cross, and Neuringer-Benefiel (1986) found that negative emotional responses often accompany empathy and precede helping behavior (as cited in Shanahan, Hopkins, and Carlson, 2010). In this study, attitude estimates were assumed to be based on beliefs and evaluations concerning public policy. In this research, the first hypothesis concerned the relationship between attitude estimates toward public policy messages and differential attitude toward public policy messages after exposure to the public policy advertising.

H1: Attitude estimates concerning public policy, such as behavioral beliefs and evaluations, affect differential attitudes after exposure to the public policy advertising. 


\section{The Effects Of Different Types Of Public Policy Advertising}

This study included a further examination of the effectiveness in the effects of attitude estimates on differential attitude between perceptions of three representative types of messages, such as print and TV advertising. For the effects of TV advertising, the impacts of direct and indirect advertising (e.g., PPL) in delivering public policy messages were measured. Grass and Wallace (1974) argued that print advertising is different from TV advertising in terms of attention level, especially due to a function of self-selection characteristics - print media relies on the self-selection process to produce ad readers, while TV depends on the self-selection process to produce commercial non-viewers (Grass and Wallace, 1974). Belch and Belch (2007) also stated that TV has numerous advantages over other media - it is superior in terms of creativity and impact, coverage and cost effectiveness, captivity and attention, and selectivity and flexibility (Belch and Belch, 2007). Childers and Houston (1984) indicated that the visual image is more powerful for information retrieval over time, while verbal materials need much more frequent exposure than visual images to obtain the desired effect. The amount of attention a person pays to advertising differs depending on the self-selective characteristics of TV viewing and print reading, which seems to be related to the difference in communication effectiveness of print and TV (Grass and Wallace, 1974). In the case of advertising that contains regulation and warning messages, such as drug advertising, print advertising had to include a brief, but detailed, summary of risk and other information. Although TV advertising was much shorter, nonetheless, it contained a lengthy major statement of risks, including adequate provisions for viewers to obtain full FDA-approved prescribing information (Calfee, 2002). This suggests that TV advertising may include more content to deliver to customers than print ads do.

A critical example of indirect TV advertisement, PPL is a way to reach audiences among the various tools of integrated mediated communication. PPL was defined as the inclusion of branded products or brand identifiers, through audio and/or visual means, within mass media programming (Karrh, 1998). It was also defined as a paid product message aimed at influencing movie (or TV) audiences via the planned and unobtrusive entry of a branded product into a movie or TV program (Balasubramanian, Karrh, and Patwardhan, 2006; Alwitt and Prabhaker, 1994). PPL has also been used to deliver regulation and warning messages as an indirect method of public policy TV advertising. For example, the Korean Ministry of Health and Welfare spent about $\$ 150,000$ of its $\$ 2,730,000$ budget allocated for non-smoking on a soap opera to conduct anti-smoking campaign in 2011 (Lee, 2011). The Korean Ministry of Environment also spent its budget on advertising its policy of saving the earth and reducing carbon consumption on PPL in a variety show. Based on these considerations, hypotheses for this study stated that the effect of attitude estimates on differential attitudes differs based on perception of media type, including print and TV advertising. For TV advertising, the differences in the effects of direct and indirect advertising were also studied.

H1a: The effect of attitude estimates on differential attitudes differs based on perception of print advertising.

H1b: The effect of attitude estimates on differential attitudes differs based on perception of direct TV advertising.

H1c: The effect of attitude estimates on differential attitudes differs based on perception of indirect TV advertising.

\section{The Effect Of Estimates Of Subjective Norm On Differential Subjective Norm}

The focus of this study was on the relationship between estimates of subjective norms concerning public policy, such as normative beliefs and motivations to comply and differential subjective norm (i.e., attitude toward public policy advertising based on subjective norm) after perceiving public policy messages. Subjective norms - an additional component of the multi-attribute attitude models - concern a person's perception of social pressure to perform or not perform the behavior under consideration (Ajzen and Fishbein, 1980; Cho and Rim, 2013). According to Ajzen (2005), subjective norms - the major determinant of intentions in the theory of planned behavior - are assumed to be a function of beliefs. However, these are beliefs of a different kind; namely, the person's beliefs that specific individuals or groups approve or disapprove of performing the behavior.

According to Blackwell, Miniard, and Engel (2006), socialization is the process by which people develop 
their values, motivations, and habitual activities or the process of absorbing a culture. Through the values transfusion model, Blackwell, Miniard, and Engel (2006) explained how the values of a society are reflected in families, religious institutions, and schools, all of which expose and transmit values to individuals. Moschis (1987) also stated that the process of consumer socialization occurs throughout life instead of during a certain period. In this context, subjective norms - an additional component to the multi-attribute attitude model that accounts for the effects of what individuals believe other people think they should do - are important determinants in explaining consumers' behaviors (Ajzen and Fishbein, 1980; Solomon, 2009).

Subjective norms are also created from normative beliefs or the total set of salient normative beliefs, each weighted by motivation to comply instead of behavioral belief (Ajzen and Fishbein, 1980). Subjective norms refer to specific behavioral prescriptions attributed to a generalized social agent; estimates of subjective norms are based on normative beliefs concerning public policy and motivations to comply (Ajzen and Fishbein, 1980). In this study, differential attitude was applied in the following hypotheses as the subjective norm for public policy messages after seeing three types of public policy advertising:

H2: Estimates of subjective norms concerning public policy, such as normative beliefs and motivations to comply, affect differential subjective norm (i.e., attitude toward public policy messages based on subjective norm) after perceiving public policy messages.

As with the first hypothesis, this study served to explore the differences between estimates of subjective norms on the differential subjective norm based on perceptions of three representative types of messages (i.e., print and direct and indirect TV advertising):

H2a: The effect of estimates of subjective norms on differential subjective norm differs based on perception of prints ads.

H2b: The effect of estimates of subjective norms on differential subjective norm differs based on perception of direct TV ads.

H2c: The effect of estimates of subjective norms on differential subjective norm differs based on perception of indirect TV ads.

\section{The Effect Of Differential Attitudes On Differential Intention}

This study was an investigation of the relationship between differential attitudes toward public policy messages and differential intention toward public policy advertising. Various studies suggested intention is a proxy measure of actual behavior and a precursor of the behavior. Ajzen and Fishbein (1980) stated that the person's intention to perform a given behavior is the immediate determinant of that behavior. Individuals will intend to perform a behavior when they evaluate it positively and when they believe that it is important others think they should perform it (Ajzen and Fishbein, 1980). Azjen (2005) argued that intention remains a behavioral disposition until, at the appropriate time and opportunity, an individual makes an attempt to translate the intention into action. Azjen (2005) also stated that intentions to engage are quite accurate predictors of a specific behavior. In particular, purchase intention is widely used as a reasonable predictor subject to appropriate calibration even though it is an imperfect predictor of actual purchasing (Sun and Morwitz, 2010; Bart, Stephen, and Sarvary, 2014). As proposed in Figure 1, this study served to explore the effects of attitude toward public policy advertising formed by attitude estimates and intention to follow public policy. Differential intention was applied as behavioral intention toward public policy after seeing different types of public policy advertising:

H3: Differential attitudes toward public policy affect differential intention to switch attitude toward public policy. 


\section{The Effect Of Differential Subjective Norm On Differential Intention}

According to Azjen (2005), the second determinant of intention is the person's perception of social pressure to perform or not perform the behavior under consideration. Ajzen and Fishbein (1980) addressed subjective norms as a social or normative component concerning the influence of the social environment on intentions and behavior. Ajzen and Fishbein (1980) also stated that people hold favorable attitudes toward behaviors that their significant others think they should perform and negative attitudes toward behaviors their significant others think they should not perform (cited in Cho and Rim, 2013). In terms of the theory of planned behavior (Azjen, 2005), the relative importance of attitude toward the behavior, subjective norm, and perceived behavioral control are dependent, in part, on the intention under investigation. Based on this consideration, this study served to investigate the effect of differential subjective norm for public policy messages on intention to follow public policy. In particular, measurements of the subjective norm, after seeing different types of public policy advertising, were examined:

H4: Differential subjective norm affect differential intention toward public policy.

\section{The Effect Of Differential Intention On Behavioral Change}

This study was also an exploration of the effect of differential intention on switching attitudes toward public policy based on behavioral change to follow the policy. Behavior refers to a consumer's actions with regard to an attitude object (Solomon, 2009). Azjen (2005) indicated that behavior can be explained by a number of concepts, including a person's accessible beliefs, such as intention. In this study, the effect of differential intention on switching attitudes toward public policy and on behavioral changes to follow the policy were measured based on different types of public policy advertising.

H5: Differential intention to switch attitude to public policy affects behavioral change to follow the public policy.

\section{METHODOLOGY}

To measure 1) the effects of attitudes, subjective norms, differential intention, and behavioral change on public policy advertising and 2) the differences in those effects based on different types of advertising, both qualitative and quantitative analyses, were employed in this study. Qualitative research was conducted first, based on the main research questions. The findings from the qualitative research resulted in more detailed research questions to test the hypotheses through quantitative research.

\section{Methodology For Qualitative Research}

The purpose of the qualitative research was to gain interviewees' opinions to develop additional research questions concerning public policy messages. The qualitative research consisted of in-depth interviews with two respondents. One interviewee was a 29 -year-old woman (student) who often watches TV - in particular, variety shows and soap operas. The other interviewee was a 30-year-old man (accountant) who views TV programs in which he has interest. Both stated that they also often read magazines and/or newspapers that include public policy advertising. The two main questions for this qualitative research were 1) how different individuals perceive public policy advertising based on the types of messages and 2) what factors contribute to follow public policy.

\section{Methodology For Quantitative Research}

The quantitative research consisted of a survey designed based on the findings from the qualitative research. The main purpose of the quantitative research was to estimate the effectiveness of public policy messages on conditional principles. To do this, the following were measured: 1) the relationships between estimate attitudes, subjective norms, differential attitudes, differential subjective norm, intentions, and behavioral change based on perceptions of public policy-related messages, especially those regarding environmental policy, and 2) the differences in effectiveness based on conditional principles, such as types of public policy messages and a method of 
exposure to the audience. Among a variety of public policy messages, in particular, the focus of this study was public policy advertising regarding environmental concerns.

Survey questions were developed and distributed for online data collection via the survey website, Qualtrics. A 7-point scale (e.g., $1=$ strongly disagree; $7=$ strongly agree) was applied for each construct. All respondents watched TV and read magazines and/or newspapers at least once a week. Respondents were randomly selected. To assess the effectiveness of public policy messages, the questionnaire include three types of public policy related advertising that concerned environmental concerns: 1) a print advertisement, 2) TV advertisement (direct exposure), and 3) PPL (indirect exposure). Respondents were exposed to three different types of advertising before answering questions and compared their effectiveness and persuasiveness.

\section{DATA ANALYSIS}

\section{Findings From Qualitative Research}

One interviewee experienced different types of public policy advertising. The respondent saw an environmental message concerning saving the earth at the beginning of the film in the theater. Although she did not recognize the message in question as a public policy message, it was impressive because saving the earth seemed to her to be a subjective norm. The respondent also saw other public policy messages, some of which have been included to facilitate the discussion. She remembered print advertising, TV advertising, and PPL of a new address system (a kind of administration policy). The print ads and TV ads did not inspire her to follow the policy, but the PPL did. She perceived the information and intended to follow. After seeing the PPL of a new address system in a variety show, she felt the new system was more effective and was an easier way to find an unfamiliar building. The PPL also showed more detail and real situations in which people adopted and followed the policy; thus, she came to know the positive aspects of following public policy in detail as she watched the message That is, showing the way to apply the product and its consequences was more effective and impressive than just providing images and offering an explanation of how to do. This could be explained as an example of observational learning, the process of imitating the behavior of others. In this context, the more detailed the ads showed, the more effective and impressive they are. This interview was instrumental in developing the research question concerning differences in individual perceptions of the different types of public policy messages.

The other interviewee could not recall any public policy-related messages. However, after being informed about public policy messages, this respondent remembered some parts of the program. He also stated that PPL was more persuasive than the TV ads, even though he did not notice that the program advertised public policy. In fact, he did not watch the TV program when it was broadcast. Instead, he selected the program to watch and skipped the advertisements. In other words, he saw the public policy messages only when the messages were indirectly advertised through PPL. However, the respondent did not think this PPL was an advertisement for public policy but presented reasonable fact. This interview was also instrumental in developing research questions concerning the differences in individual perception of public policy messages based on the types of the messages.

\section{Findings From Quantitative Research}

\section{Demographic Information}

Of the 197 participants, approximately $62.9 \%$ were male and $37.1 \%$ were female. Approximately $51 \%$ were single and $49 \%$ were married. In terms of highest level of education attained, $46.9 \%$ of the participants had bachelor degrees, $39.2 \%$ had master degrees, $6.2 \%$ completed high school, $4.1 \%$ had associate degrees, and $3.6 \%$ had doctoral degrees. Approximately $9.4 \%$ indicated their annual household income was $\$ 20,000$ or under, $32.4 \%$ earned between $\$ 20,000$ and $\$ 40,000,27.1 \%$ earned between $\$ 40,000$ and $\$ 60,000,14.1 \%$ earned between $\$ 60,000$ and $\$ 80,000,7.1 \%$ earned between $\$ 80,000$ and $\$ 100,000$, and $10 \%$ earned more than $\$ 100,000$. Approximately, $35.4 \%$ of the respondents were in the $20-29$ years old age group, $29.2 \%$ were $30-39,28.1 \%$ were $40-49$, and $7.3 \%$ were 50-59. Approximately $49.5 \%$ were businessmen, $18.6 \%$ were government officers, $13.4 \%$ were students, $13.4 \%$ were professionals, $2.1 \%$ were housewives, and $1 \%$ were nonprofit organization workers. 


\section{Reliability Test: Cronbach Alpha}

To test reliability for each item of the model, Cronbach alpha was employed as the reliability coefficient (see Table 1). To measure attitude estimates, 10 questions were asked. The alpha was .9041, which implies that all of the questions concerning attitude estimates in the survey had consistency. Cronbach alpha for questionnaire items asking differential attitude was .9470. Questionnaire items concerning estimates of subjective norms had an alpha of .8569. For differential subjective norm, the alpha was .8774. Questionnaire items concerning differential intention had an alpha of .8496. For the last item - behavioral change - the alpha was .8420 .

Table 1: Results Of Test Of Reliability (Cronbach's Alpha)

\begin{tabular}{|l|l|}
\hline Questionnaire Items & Reliability Coefficients \\
\hline Attitude Estimates & 0.9041 \\
\hline Differential Attitude & 0.9470 \\
\hline Estimates of Subjective norm & 0.8569 \\
\hline Differential Subjective norm & 0.8774 \\
\hline Differential Intention & 0.8496 \\
\hline Behavioral Change & 0.8420 \\
\hline
\end{tabular}

Hypotheses Test

To analyze the hypotheses, factor and regression analyses, Analysis of Variance (ANOVA), and Analysis of Co-Variance (ANCOVA) were employed. For factor analysis, the extraction method and Varimax rotation methods with Kaiser Normalization were used and the most relevant data emerged. Factor scores and factor coefficients from factor analysis were used for regression analyses. Items were identified as factors if they had Eigenvalues greater than one.

Factor analysis was performed on the 34 variables in six categories. In the process, some variables were excluded from the analysis because of their low communalities, while 23 items were used to obtain the final sixfactor solution using principal component analysis with the varimax rotation: 1) attitude estimates based on beliefs and evaluations concerning public policy, 2) differential attitude toward public policy message, 3) estimates of subjective norm concerning public policy message, iv) differential subjective norm for public policy advertising, v) differential intention to follow public policy, and vi) behavioral change to follow public policy. These factors were grouped as variables when eigenvalues were over 1.00 (see Table 2). 
Table 2: Component Matrix: Factors That Affect Effectiveness Of Public Policy Advertising On Conditional Principles

\begin{tabular}{|c|c|c|c|c|c|c|c|}
\hline \multicolumn{2}{|r|}{ Items } & \multicolumn{6}{|c|}{ Component } \\
\hline External Factors & Scale Items & 1 & 2 & 3 & 4 & 5 & 6 \\
\hline Attitudes 1 & I would have better life if I comply with public policy. & .860 & & & & & \\
\hline Attitudes 2 & $\begin{array}{l}\text { If I follow public policy (e.g. environmental policy- } \\
\text { energy saving), quality of my life will be improved. }\end{array}$ & .858 & & & & & \\
\hline Attitudes 3 & $\begin{array}{l}\text { I am willing to reduce energy consumption due to } \\
\text { public policy-related messages such as environment. }\end{array}$ & .833 & & & & & \\
\hline Attitudes 4 & $\begin{array}{l}\text { I think public policy-related messages (e.g. energy } \\
\text { saving) are effective and persuasive. }\end{array}$ & .799 & & & & & \\
\hline Differential Att 1 & $\begin{array}{l}\text { I feel that I need to reduce or moderate my energy } \\
\text { consumption by seeing those environmental policies. }\end{array}$ & & .874 & & & & \\
\hline Differential Att 2 & $\begin{array}{l}\text { After I see public policy-related advertisements, I } \\
\text { think I would have better life if I comply with them. }\end{array}$ & & .872 & & & & \\
\hline Differential Att 3 & $\begin{array}{l}\text { I think public policy-related advertisement is } \\
\text { informative and believable. }\end{array}$ & & .866 & & & & \\
\hline Differential Att 4 & $\begin{array}{l}\text { Public policy-related advertisements alarm me to } \\
\text { reduce or moderate energy consumption. }\end{array}$ & & .814 & & & & \\
\hline Differential Att 5 & $\begin{array}{l}\text { Environmental policy-related messages alarm me of } \\
\text { my reduction or moderation toward energy } \\
\text { consumption. }\end{array}$ & & .798 & & & & \\
\hline Differential Att 6 & $\begin{array}{l}\text { As the voice of public policy-related advertisements is } \\
\text { more specific, I tend to follow the public policy. }\end{array}$ & & & .854 & & & \\
\hline $\begin{array}{l}\text { Subjective Norm } \\
1\end{array}$ & $\begin{array}{l}\text { If most people who are important to me have an } \\
\text { energy moderation attitude, I think I can more easily } \\
\text { reduce or moderate my energy consumption attitude. }\end{array}$ & & & .831 & & & \\
\hline $\begin{array}{l}\text { Subjective Norm } \\
2\end{array}$ & $\begin{array}{l}\text { I think that I should reduce or moderate my energy } \\
\text { consumption attitude when I see public policy } \\
\text { advertising. }\end{array}$ & & & .793 & & & \\
\hline $\begin{array}{l}\text { Subjective Norm } \\
3\end{array}$ & $\begin{array}{l}\text { If most people who are important to me decide to } \\
\text { reduce or moderate their energy consumption, I would } \\
\text { support their decision. }\end{array}$ & & & & .894 & & \\
\hline $\begin{array}{l}\text { Differential } \\
\text { Subjective Norm } \\
1\end{array}$ & $\begin{array}{l}\text { I think that public policy-related messages (e.g. } \\
\text { environmental policy) strengthen my subjective norm. }\end{array}$ & & & & .838 & & \\
\hline $\begin{array}{l}\text { Differential } \\
\text { Subjective Norm } \\
2\end{array}$ & $\begin{array}{l}\text { After I perceive environmental policy-related } \\
\text { messages (e.g. response to climate change), I consider } \\
\text { reducing or moderating energy consumption for social } \\
\text { obligatory. }\end{array}$ & & & & .813 & & \\
\hline $\begin{array}{l}\text { Differential } \\
\text { Subjective Norm } \\
3\end{array}$ & $\begin{array}{l}\text { If my family members or relatives have a positive } \\
\text { attitude toward environmental policy-related } \\
\text { messages, I think that I also would have a positive } \\
\text { attitude toward them. }\end{array}$ & & & & & .890 & \\
\hline Intention 1 & $\begin{array}{l}\text { I'm willing to switch my energy consumption attitude } \\
\text { by seeing those carbon-usage warning (moderation) } \\
\text { advertising. }\end{array}$ & & & & & .864 & \\
\hline Intention 2 & $\begin{array}{l}\text { Sometimes environmental warning (moderation) } \\
\text { messages give me reaction to using energy less. }\end{array}$ & & & & & .729 & \\
\hline Intention 3 & $\begin{array}{l}\text { I tend to save the energy due to many reasons, such as } \\
\text { environmental concern. }\end{array}$ & & & & & & .877 \\
\hline Intention 4 & $\begin{array}{l}\text { I have a tendency to reduce or moderate energy } \\
\text { consumption. }\end{array}$ & & & & & & .867 \\
\hline Behavioral & I'll start to reduce or moderate my energy & & & & & & \\
\hline $\begin{array}{l}\text { Change } 1 \\
\text { Behavioral }\end{array}$ & $\begin{array}{l}\text { consumption attitude. } \\
\text { I have a plan to start reducing (moderating) my energy }\end{array}$ & & & & & & .852 \\
\hline $\begin{array}{l}\text { Benavioral } \\
\text { Change } 2\end{array}$ & $\begin{array}{l}\text { I have a plan to start reaucing (moderating) my energy } \\
\text { consumption attitude soon. }\end{array}$ & & & & & & \\
\hline $\begin{array}{l}\text { Behavioral } \\
\text { Change3 }\end{array}$ & $\begin{array}{l}\text { The above public policy-related messages have a } \\
\text { positive affect to switch my behavior. }\end{array}$ & & & & & & \\
\hline
\end{tabular}


Table 3 contains the results of the regression analyses using factor scores for the effects of proposed factors. The effects of attitude estimates on differential attitude toward public policy advertising indicated the model was significant at the $\alpha=0.01$ level, with $r$-square $=.343$ and the effects of estimates of subjective norms on differential subjective norms indicated the model was significant at the $\alpha=0.01$ level, with $r$-square $=.458$. Therefore, hypotheses 1 and 2 were accepted. This study also showed that the effects of differential attitude on intention were significant at the $\alpha=0.01$ level, with $r$-square $=.569$; effects of differential subjective norms on intentions showed the model was significant at the $\alpha=0.01$ level, with $r$-square $=.586$; and effects of differential intention on behavioral change were significant at the $\alpha=0.01$ level, with $r$-square $=.728$. Therefore, hypotheses 3,4 , and 5 were also accepted.

Table 3: Summary Of The Effects Of Attitude Estimates, Differential Attitude,

Estimates Of Subjective Norms, Differential Subjective Norm, Differential Intention, And Behavior Change

\begin{tabular}{|l|l|}
\hline \multicolumn{1}{|c|}{ Variable (Independent $\boldsymbol{~}>$ Dependent) } & Standardized Coefficient $(\boldsymbol{t}$-value-Sig) \\
\hline Attitude Estimates -> Differential Attitude (H1) & $0.586\left(9.147^{* *}\right)$ \\
\hline Estimates of Subjective Norms -> Differential Subjective Norm (H2) & $0.677\left(12.303^{* * *)}\right.$ \\
\hline Differential Attitude -> Differential Intention (H3) & $0.754\left(14.883^{* *}\right)$ \\
\hline Differential Subjective Norm -> Differential Intention (H4) & $0.765\left(16.081^{* *}\right)$ \\
\hline Differential Intention -> Behavioral Change (H5) & $0.853\left(21.912^{* * *)}\right.$ \\
\hline$* * *$ Significant at 0.01 level (2-tailed)
\end{tabular}

*** Significant at 0.01 level (2-tailed)

ANCOVA was used to test hypotheses H1a c and H2a c. Table 4 shows the results for effects based on the different types of media; i.e., print and direct and indirect TV advertising. Table 4 shows effects of attitude estimates on differential attitude (1a for print, $1 \mathrm{~b}$ for direct TV, and $1 \mathrm{c}$ for indirect TV advertising) and effects of estimates of subjective norms on differential subjective norm ( $2 \mathrm{a}$ for print, $2 \mathrm{~b}$ for direct $\mathrm{TV}$, and $2 \mathrm{c}$ for indirect TV advertising). As shown in Table 4, effects of attitude estimates on differential attitude were significant $\alpha=.01$ ( $F=$ 29.955 for print, 21.819 for direct TV, and 11.486 for indirect TV advertising). Effects of estimates of subjective norms on differential subjective norm $(F=10.313$ for print, 5.055 for direct TV, and 5.260 for indirect TV advertising) were also significant at $\alpha=.01$. Results of ANCOVA showed that the impacts of attitude estimates on differential attitude and estimates of subjective norms on differential subjective norm were different based on media types. Therefore, hypotheses $1 \mathrm{a} \sim \mathrm{c}$ and $2 \mathrm{a} \sim \mathrm{c}$ were accepted.

Table 4: Summary Of The Effects Based On Print And Direct And Indirect TV Advertising

\begin{tabular}{|c|c|c|c|}
\hline & \multicolumn{3}{|l|}{$F$ (Sig) } \\
\hline Effects Based On Media Type & Print Advertising & $\begin{array}{l}\text { Direct TV } \\
\text { Advertising }\end{array}$ & $\begin{array}{l}\text { Indirect TV } \\
\text { Advertising }\end{array}$ \\
\hline Attitude Estimates -> Differential Attitude (H1a c) & $29.955(0.000 * * *)$ & $21.819(0.000 * * *)$ & $11.486(0.000 * * *)$ \\
\hline $\begin{array}{l}\text { Estimates of Subjective Norms } \rightarrow \text { Differential } \\
\text { Subjective Norm }(\mathrm{H} 2 \mathrm{a} \sim \mathrm{c})\end{array}$ & $10.313(0.000 * * *)$ & $5.055(0.000 * * *)$ & $5.260(0.000 * * *)$ \\
\hline
\end{tabular}

\section{CONCLUSION}

The focus of this study was measurement of the effects of public policy-related advertising through the application of the extended Fishbein model (1980) and included measurement of the relationships of 1) the effect of attitude estimates on differential attitudes; 2) the effect of estimates of subjective norm on differential subjective norm; 3) the effect of differential attitude and subjective norm on differential intention; and iv) the effect of differential intention on behavioral change. In particular, this study served to measure the differences in those effects based on perceptions of media types. Results of the statistical analyses revealed that all the proposed effects were statistically significant. Thus, the study suggested that public policy advertising significantly affects public attitudes, subjective norms, intention, and behavior to follow those messages.

This study revealed both managerial and theoretical implications. Theoretically, the study served to develop and apply the extended Fishbein Model to analyze the effect of public policy advertising on attitudes and behavioral changes. This study also involved the application of conditional principles for exploring the differences between the effect of attitude estimates on differential attitudes and the effects of subjective norm estimates on differential 
subjective norm for print and direct and indirect TV advertising. Academically, the study is another contribution to the development of public policy issues with the implication that the public sector should adopt the theoretical background of marketing. Studies in the public sector indicated that adoption of such marketing principles was not widespread. As the study revealed, nonprofit and social organizations should not only adopt marketing and advertising theories in transmitting their messages but also employ both qualitative and quantitative analyses.

Managerially, this study revealed the relationship between attitude and behavior in adopting public policy advertising, which were rarely applied in previous studies. Understanding public attitudes and behavior should result in building the importance of public-centered management.

The study was not without limitations and could be extended by increasing the sample size to enhance generalizability. Qualitative research was applied but not used for hypotheses testing. With improved sample size, future studies could reveal more in-depth analysis based on qualitative research. Also, future studies should be conducted to examine the effects of variables in terms of cause-and-effect relationships. Effects of other media types should also be measured so that the findings might be applied to various cases.

\section{AUTHOR INFORMATION}

Professor Cho received MBA from Cornell and Ph.D. in Management from Rutgers University. She was associate professor at Hawaii Pacific University and currently professor at the KDI School of Public Policy and Management, Seoul, Korea. She published research papers in the various academic journals such as Journal of Business Research (JBR), Advances in Consumer Research (ACR), Journal of Business \& Economics Research (JBER), etc. E-mail: ycho@kdischool.ac.kr (Corresponding author).

Yun, Bichwi received master degree from the KDI School of Public Policy and Management and currently work at the Korea Institute for Development Strategy (KDS). E-mail: bichwi@gmail.com

\section{REFERENCES}

1. $\quad$ Aaker, D. A., Kumar, V., and Day, G. S. Marketing Research. USA: John Wiley and Sons, 2001.

2. Ajzen, Icek and Fishbein, Martin. Understanding Attitudes and Predicting Social Behavior. New Jersey: Prentice-Hall, 1980.

3. Ajzen, Icek (2005), Attitudes, Personality, and Behavior, $2^{\text {nd }}$ edition, Open University Press.

4. Alwitt, Linda and Prabhaker, Paul (1994), "Identifying who dislikes television advertising: Not by demographics alone," Journal of Advertising Research. Vol. 34, No. 6, pp. 17-29.

5. Andreasen, Alan R. Rethinking the relationship between Social/Nonprofit marketing and commercial marketing. Journal of Public Policy \& Marketing. Vol. 31, No. 1, pp. 36-41, 2012.

6. Andrews, K. H. and Kandel, D. B. (1979), "Attitude and Behavior: A Specification of the Contingent Consistency Hypothesis,” Annual Sociology Review, 44, 298-310.

7. Arnold, Denis G. and Oakley, James L. (2013), "The Politics and Strategy of Industry Self-Regulation: The Pharmaceutical Industry's Principles for Ethical Direct-to-Consumer Advertising as a Deceptive Blocking Strategy," Journal of Health Politics, Policy, and Law, 38(3), June, 505-544.

8. Arnould, Eric, Zinkhan, George, and Price, Linda (2002), Consumers. McGraw-Hill Higher Education.

9. Bagozzi, Richard P. and Moore, David J. (1994), "Public Service Advertisements: Emotions and Empathy Guide Prosocial Behavior," Journal of Marketing. Vol. 58, No. 1, 56-70.

10. Balasubramanian, Siva K. (1994), "Beyond Advertising and Publicity: Hybrid Messages and Public Policy Issues," Journal of Advertising, 23(4), December, 29-46.

11. Balasubramanian, Siva K., Karrh, J. A., and Patwardhan, H. (2006), “Audience Response to Product Placements: An Integrated Framework and Future Research Agenda, Journal of Advertising," 35(3), 115141.

12. Banura, Albert (1986), Social Foundations of Thought and Action: A Social-Cognitive View. Upper saddle river, NJ: Prentice Hall.

13. Barlow, Todd and Wogalter, Michael S. (1993), "Alcoholic beverage warnings in magazine and television advertisements," Journal of Consumer Research. Vol. 20, No. 1, pp. 147-156. 
14. Bart, Yakov, Stephen, Andrew T., and Sarvary, Miklos (2014), "Which Products are Best Suited to Mobile Advertising? A Field Study of Mobile Display Advertising Effects on Consumer Attitudes and Intentions," Journal of Marketing Research, Vol. LI, June, 270-285.

15. Batson, C. Daniel, Bolen, Michelle H., Cross, Julie A., and Neuringer-Benefiel, Helen E. (1986), "Where is the altruism in the altruistic personality?" Journal of Personality and Social Psychology. Vol. 50, No. 1, 212-220.

16. Beck-Dudley, Caryn L. and Williams, Terrell G. (1989), "Legal and Public Policy Implications for the Future of Comparative Advertising: A Look at U-Haul vs. Jartan,” Journal of Public Policy and Marketing, Vol.8, 124-142.

17. Belch, George and Belch, Michael (2007), Advertising and Promotion - an Integrated Marketing Communications Perspective. 7th edition ed. New York, NY: McGraw-Hill/Erwin.

18. Bergen, Daniel and Risner, Genevieve (2012), "The Power of Citizen-Group Public-Policy Advertisng: Messages Don't Need Third-Party Validation to Increase Salience among Pockets of Voters," Journal of Advertising Research, December, 405-420.

19. Blackwell, Roger D., Miniard, Paul W., and Engel, James F. (2006), Consumer Behavior. 10th edition ed. Australia: Thomson South-Western.

20. Boddewyn, Jean J. (1989), “Advertising Self-Regulation: True Purpose and Limits,” Journal of Advertising, 18(2), 19-27.

21. Briey, Donnel A., Shrum, L.J., and Wyer, Robert S. Jr. (2013), "Factors Affecting Judgments of Prevalence and Representation: Implications for Public Policy and Marketing, Journal of Public Policy \& Marketing, 32 (Special Issue), 112-118.

22. Brockett, Patrick L., Golden, Linda L. and Aird, Paul (1990), "How Public Policy Can Define the Marketplace: The Case of Pollution Liability Insurance in the 1980s," Journal of Public Policy \& Marketing, Vol.9, 211-226.

23. Calfee, John E. (2002), "Public policy issues in direct-to-consumer advertising of prescription drugs," Journal of Public Policy \& Marketing, Vol. 21, No. 2, 174-193.

24. Childers, Terry L. and Houston, Michael J. (1984), "Conditions for a Picture-Superiority Effect on Consumer Memory,” Journal of Consumer Research. Vol. 11, No. 2, 643-654.

25. Cialdini, Robert, B., Petty, Richard, E., and Cacioppo, John T. (1981), "Attitude and Attitude Change,” Annual Review of Psychology, 32, 357-404.

26. Cho, Yoon C. and Rim, Jihoon (2013), "Exploring Warning Messages On Conditional Principles \& Predicting Social Behavior,” Journal of Business and Economics Research, Vol.11, No.11, November, 469-484.

27. Cobuild (2001), Collins Cobuild Dictionary, Westerhill Road, Bishopbriggs: HarperCollins Publishers.

28. Falk, E., Grizard, E., and McDonald G. (2005), "Legislative Issue Advertising in the $108^{\text {th }}$ Congress," Retrieved on November 20, 2008 from the Annenberg Public Policy Center Web Site.

29. Grass, Robert C. and Wallace, Wallace H. (1974), “Advertising communication: Print vs. TV," Journal of Advertising Research. Vol. 14, No. 5, 19-23.

30. Hausman, Angela (2008), "Direct-to-Consumer Advertising and Its Effect on Prescription Requests," Journal of Advertising Research, 48(1), March, 42-56.

31. Heath, Robert L. and Nelson, Richard Alan (1985), "Image and Issue Advertising: A Corporate and Public Policy Perspective, Journal of Marketing, Spring, 49, 58-68.

32. Jacobson, Robert and Nicosia, Franco M. (1981), “Advertising and Public Policy: The Macroeconomic Effects of Advertising," Journal of Marketing Research, 18, February, 29-38.

33. Kahle, L. R. and Berman, J. J. (1979), “Attitudes Cause Behaviors: A Cross-Lagged Panel Analysis,” Journal of Personality and Social Psychology, 37, 315-321.

34. Karrh, J. A. (1998), "Brand Placement: A Review," Journal of Current Issues and Research in Advertising, Vol. 20, Issue 2, 32-49.

35. Lee, Gi-hyun (2011), "Indirect Advertising (PPL) in Soap Opera and Story Telling", Korea Creative Contents Agency Focus (KOCCA), No. 32, 1-50.

36. Levitt, Theodore (1960), "Marketing myopia," Harvard Business Review. Vol. 38, July-August, 57-66.

37. Liu, Qiang and and Gupta, Sachin (2011), "The Impact of Direct-to-Consumer Advertising of Prescription Drugs on Physician Visits and Drug Requests: Empirical Findings and Public policy Implications," International Journal of Research in Marketing, 28(3), September, 205-217. 
38. Lutz, Richard J. (1978), “A functional approach to consumer attitude research,” Advances in Consumer Research. Vol. 5, No. 1, 360-369.

39. Moschis, George P. (1987), Consumer Socialization. Lexington, MA: Lexington Books.

40. Murphy, Patrick E. (2011), "The Early Years of Journal of Public Policy \& Marketing," Journal of Public Policy \& Marketing, 30(1), Spring, 64-67.

41. Rotfeld, Herbert Jack and Stafford, Marla Royne (2006), "Pragmatism and Realities for Understanding the Advertising and Public Policy Literature," American Academy of Advertising Conference, 209-210.

42. Rotfeld, Herbert Jack and Stafford, Marla Stafford (2007), "Toward a Pragmatic Understanding of the Advertising and Public Policy Literature," Journal of Current Issues and Research in Advertising, 29(1), Spring, 67-80.

43. Sethi, Prakash S. (1979), "Institutional/Image Advertising and Idea/Issue Advertising as Marketing Tools: Some Public Policy Issues,” Journal of Marketing, 43, January, 68-78.

44. Shanahan, Kevin J., Hopkins, Christopher D., and Carlson, Les. (2010), "The unintended Consequences of Using Posers in Nonprofit Public Service Announcements and Proposed Self-Regulatory Disclosure Solutions," Journal of Public Policy \& Marketing. Vol. 29, No. 2, 219-231.

45. Smith, N. Craig, Drumwright, Minette E., and Gentile, Mary C. (2010), "The New Marketing Myopia," Journal of Public Policy \& Marketing. Vol. 29, No. 1, 4-11.

46. Solomon, Michael R. (2009), Consumer Behavior: Buying, having, and being. 8th edition ed. Upper Saddle River, NJ: Pearson/Prentice Hall.

47. Stewart, David W. and Martin, Ingrid M. (1994), "Intended and Unintended Consequences of Warning Messages: A Review and Synthesis of Empirical Research,” Journal of Public Policy \& Marketing. Vol. 13, No. 1, 1-19.

48. Stewart, David W. (2013), "Reinventing Marketing and Public Policy for the Twenty-First Century: An Editorial Statement," Journal of Public Policy \& Marketing, 32(1), Spring, 1-5.

49. Sun, Baohong and Morwitz, Vicki G. (2010), "Stated Intentions and Purchase Behavior: A Unified Model," International Journal of Research in Marketing, 27(4), 356-66.

50. Taylor, Charles R. (2009), “On the Need for Advertising and Public Policy Research, International Journal of Advertising, 28(4), 601-604.

51. Torres, Ivonne M., Sierra, Jeremy J., and Heiser, Robert S. (2007), "The Effects of Warning-Label Placement in Print ads," Journal of Advertising, Vol. 36, No. 2, 49-62.

52. Wei-Skellern, Jane, Austin, James E., Leonard, Herman, and Stephenson, Howard (2007), Entrepreneurship in the Social Sector, Thousand Oaks, CA: Sage Publications.

53. Wilkie, William L. and Gardner, David M. (1974), "The Role of Marketing Research in Public Policy Decision Making," Journal of Marketing. Vol. 38, No. 1, 38-47. 